\title{
Cytotoxic Effects of Valsartan Organotin(IV) Complexes on Human Lung Cancer Cells
}

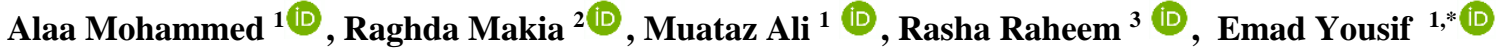 \\ 1 Department of Chemistry, College of Science, Al-Nahrain University, Baghdad, Iraq; alaaalqaycy7@gmail.com (A.M.), \\ muataz.a.ali@gmail.com (M.A.); \\ 2 College of Biotechnology, Al-Nahrain University, Baghdad, Iraq; raghdahmakia@gmail.com (R.M); \\ 3 Department of Pathology, Microbiology, and Immunology, University of South Carolina School of Medicine, Columbia, \\ SC, United States of America; rasha.raheem@gmail.com (R.R); \\ * Correspondence: e emad_yousif@hotmail.com;
}

Scopus Author ID 26533612800

Received: 20.06.2020; Revised: 13.07.2020; Accepted: 14.07.2020; Published: 19.07.2020

\begin{abstract}
The organotin(IV) compounds used in chemotherapy due to its lipophilicity, affected by the number of carbon atoms and the cytotoxicity. These are affected by the obtainability of Sn coordination bond and bond stabilization between ligand and tin. Two novel organotin(IV) complexes were synthesized, characterized, and tested against human lung cancer cells (A549). The cytotoxic effect of the prepared organotin(IV) complexes against human lung cancer cells (A549) was investigated using the MTT colorimetric assay. Apoptosis was investigated by flow cytometry. The cytotoxicity assay reveals that the $\mathrm{Bu}_{2} \mathrm{SnL}_{2}$ complex is more active to inhibit the growth of A549 cells compared to the $\mathrm{Ph}_{2} \mathrm{SnL}_{2}$, and doxorubicin, nevertheless at high concentration (50 and 100) $\mu \mathrm{g} / \mathrm{mL}$ the doxorubicin was more affective to inhibit the viability of A549 cells.
\end{abstract}

Keywords: organotin(IV); valsartan; anti-cancer; A5493; IC 50 ; MTT; flow cytometry; Apoptosis.

(C) 2020 by the authors. This article is an open-access article distributed under the terms and conditions of the Creative Commons Attribution (CC BY) license (https://creativecommons.org/licenses/by/4.0/).

\section{Introduction}

Tin forms several organic compounds called organotin compounds that have at least one covalent bond between tin and carbon atoms; these compounds possess industrial and pharmaceutical importance [1]. Historically, the first preparation of the organotin compounds' indirect method was in 1849 by Frankland from heated ethyl iodide and tin; the result was crystals of diethyltin diiodide [2]. The organotin(IV) compounds got recognized as chemotherapy based on metallotherapeutic drugs obtained after cis-platin discovered in 1969 [3].

Organotin (IV) compounds showed high antitumor activity against different types of cancer with very low doses, such as ovarian, lung, epidermoid, lymphomas, cervical, bladder, germ cell, and many others. The cancer cells undergo apoptosis, the programmed cell death; the cells also face the lipophilicity, the effect of carbon atoms [4-6]. Clear evidence of this therapeutic activity of di-organotin(IV) complexes $\left(\mathrm{R}_{2} \mathrm{SnL}_{2}\right.$ where $\mathrm{R}$ are $\mathrm{Me}, \mathrm{Et}, \mathrm{Bu}, \mathrm{Ph}$ or $\mathrm{Bz}$ and $\mathrm{L}$ is 2-phenylmono-methylglutarate), the diethyltin(IV) complex showed a visible activity against human epidermoid cancer (KB cell lines) better than cisplatin [7].

Chemically, the cytotoxic activity of organotin(IV) complexes affected by obtainability of coordination bond at $\mathrm{Sn}$ and the bond stabilization between ligand and tin such as $\mathrm{Sn}-\mathrm{S}$ and 
Sn-N in ligands like acrylates, Schiff bases, acetic acid, xylene, etc. The significant role of the complexes played by the alkyl or aryl groups, while ligand represents the secondary role [8].

The malignant cells lead to metastasis, which can happen in practically all the positions of the body so that there are more than 100 different kinds of malignancies. Lung cancer leading to death overall percent exceeds that of the breast, colon, and prostate cancers. Worldwide one million deaths annually as a result of lung cancer, which means it is truly plague. The primary cause is usually attributed to cigarette smoking with a proportion of $80 \%$, while asbestos, other vocational and environmental exposures, and the genetic factors contributed to the rest [9]. In the eukaryotic cell cycle, the first phase of the period is called the G1 phase (Gap 1), which precedes the DNA replication. In this phase, the cell grows in size and increases in the number of proteins and the number of organelles (such as mitochondria and ribosome). Follows that DNA replication, which occurs during the $S$ (synthesis) phase. Next step, the G2 phase (Gap 2 ) occurs, in which the proteins synthesis and cell growth to prepare the cell to the mitosis (M) phase. In this phase, the chromosomes in the cell nucleus separated into two identical sets in two nuclei. In the G0 phase, the cell stopped dividing and have gone out of the cell cycle [10].

Valsartan chemically is $\mathrm{N}-\{4-[(1-(1 \mathrm{H}-$ tetrazole-5-yl)phenyl)benzyl $\}-\mathrm{N}$-valeryl-Lvaline, and it is a medication that is mainly used to reduce high blood pressure and to treat heart failure cases. It has a high molecular weight (435.5) and a high aromatic content (two aryl groups and a tetrazole ring), and it contains a high proportion (27\%) of heteroatoms (nitrogen and oxygen) [11-12]. This study aims to evaluate the cytotoxicity of the valsartan organotin complexes against A549 cells.

\section{Materials and Methods}

\subsection{Cytotoxicity assay.}

The cytotoxic activity of samples stock solution was performed by using MTT assay. Tumor cell line A549 (Human Lung Cancer Cell line) was were grown in DMEM media supplemented with $100 \mu \mathrm{g} / \mathrm{mL}$ streptomycin, $100 \mathrm{units} / \mathrm{ml}$ penicillin, and $10 \%$ heat-inactivated fetal bovine serum in a humidified and $5 \%(\mathrm{v} / \mathrm{v}) \mathrm{CO}_{2}$ atmosphere at $37^{\circ} \mathrm{C}$. Cells were seeding twice a week, they were grown in 96 flat well micro-titer plates $\left(10^{4}-10^{6}\right.$ cells/well $)$, in a final volume of $200 \mu \mathrm{L}$ complete culture medium per each well. Plates were incubated at $37{ }^{\circ} \mathrm{C}, 5 \%$ $\mathrm{CO}_{2}$ for $24 \mathrm{~h}$. The media were removed, and the wells were washed once by PBS, and two-fold serial concentrations of the samples under test $(0,6.5,12.5,25,50$, and $100 \mu \mathrm{g} / \mathrm{ml})$ were added to the cell monolayer. The assay was conducted in triplicates for each dose and incubated for 48 hours at $37{ }^{\circ} \mathrm{C}$ in a $5 \% \mathrm{CO}_{2}$ incubator. After incubation, $20 \mu \mathrm{L}$ of MTT solution was added to each well, mix well, and incubated again at $37^{\circ} \mathrm{C}, 5 \% \mathrm{CO}_{2}$ for 4 hours in the dark. To dissolve the formed crystals, $50 \mu \mathrm{L}$ acidic isopropanol was added to each well and incubated $4 \mathrm{~h}$ at 37 ${ }^{\circ} \mathrm{C}$ in the dark. The absorbance was measured using ELISA Reader-measure OD at $570 \mathrm{~nm}$ (background wavelength is $630 \mathrm{~nm}$ ). The $\mathrm{IC}_{50}$ values will be calculated using sigmoidal concentration-response curve fitting models (Sigmaplot software) [13].

\subsection{Cell cycle analysis.}

The principle of the Annexin V apoptosis detection kit is set up on the perception. When the apoptosis occurs, the cells transfer the membrane phosphatidylserine (PS) from the internal surface of the plasma membrane to the outer cell surface. The moment that the PS appear on the cell surface can be easily discovered via staining with a fluorescent joint of Annexin V, 
which the protein has an affinity towards PS. These detections can be tested by flow cytometry (an instrument, characterize the cells as they pass in a flow-through a laser beam. The irradiated cells show several types of signals that are detected, convert to digital data, and analyzed by computer) or by fluorescence microscopy. According to this kit, it can distinguish between apoptosis and necrosis through both Annexin V-FITC and PI staining [14].

Annexin V-FITC assay protocol includes collecting $5 \times 10^{5}$ A549 cells by centrifugation and re-suspend cells in $500 \mu \mathrm{L}$ of Binding Buffer. After that, $5 \mu \mathrm{L}$ of Annexin V-FITC and 5 $\mu \mathrm{L}$ of propidium iodide ( PI $50 \mathrm{mg} / \mathrm{ml}$ ) were added to the cell suspension. The mixtures were incubated at room temperature for $5 \mathrm{~min}$ in the dark. Analyze Annexin V-FITC binding by flow cytometry $(E x=488 \mathrm{~nm} ; \mathrm{Em}=530 \mathrm{~nm}$ ) using FITC signal detector (usually FL1) and PI staining by the phycoerythrin emission signal detector (usually FL2).

For detection by fluorescence microscopy, place the cells suspension on a glass slide and cover the cells with a glass coverslip. The cells under a fluorescence microscope Observe using a dual filter set for FITC and rhodamine.

\subsection{Statistical analysis.}

The Statistical Analysis System- SAS (2012, Statistical Analysis System, User's Guide. Statistical. Version 9.1.th ed. (SAS. Inst. Inc. Cary. N.C., USA) program has been used to estimate the effect of variable factors on the main study. Least Significant Difference (LSD) test (Analysis of Variation-ANOVA) has been used in this study to considerably compare means.

\section{Results and Discussion}

\subsection{Synthesis and Characterization of Organotin(IV) complexes.}

The ligand (valsartan) and the synthesized complexes $\left(\mathrm{Ph}_{2} \mathrm{SnL}_{2}\right.$ and $\left.\mathrm{Bu}_{2} \mathrm{SnL}_{2}\right)$ were characterized by elemental analyses, flame atomic absorption spectrophotometer, FT-IR, proton nuclear magnetic resonance $\left({ }^{1} \mathrm{H}-\mathrm{NMR}\right)$ and tin-119 nuclear magnetic resonance $\left({ }^{119} \mathrm{Sn}-\right.$ NMR) spectroscopy in recent research [15]. According to the instrumental characterizations, bonding occurs between the tin and the hydroxyl oxygen of the ligand carboxylic acid. The ligand was asymmetry bi-dentate, which reveals that organotin(IV) complexes are hexacoordinated as shown in Figure 1.

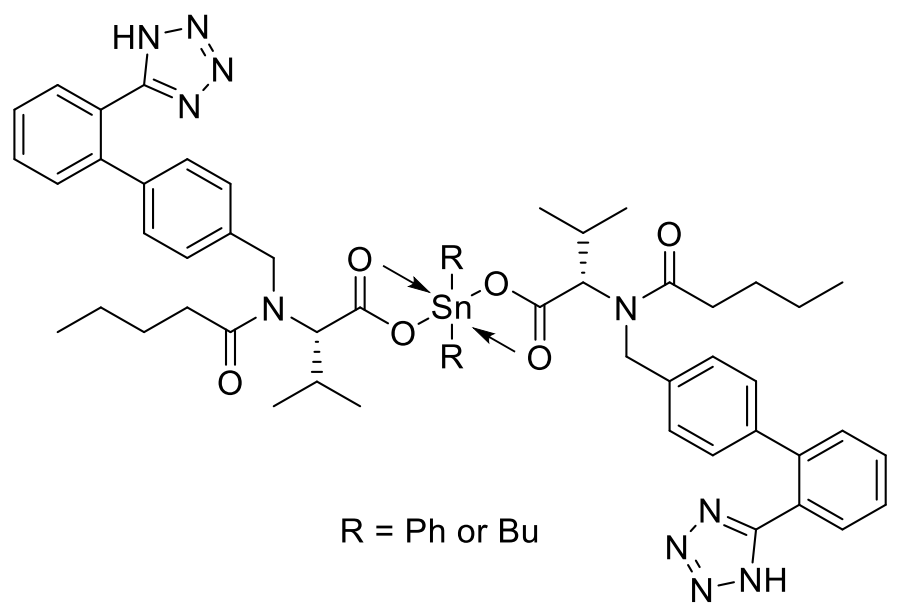

Figure 1. Structure of di-organotin(IV) complexes. 


\subsection{Cytotoxic effect of Organotin(IV) complexes.}

The cytotoxic effect of the di-organotin(IV) complexes against human lung cancer cells (A549) was investigated using MTT colorimetric assay; which is based on the color reduction of 3-(4,5-dimethyl-2-thiazolyl)bromide-2,5-diphenyl-2Htetrazolium from yellow to purple formazan due to the mitochondrial dehydrogenases of the living cells after apoptosis [16,17]. The di-organotin(IV) complexes and doxorubicin were dissolved in acidic isopropanol solvent and diluted with culture medium. Doxorubicin drug used for comparison. The human lung cancer cells (A549) were grown in culture medium and treated with $(0,6.25,12.5,25,50$, and 100) $\mu \mathrm{g} / \mathrm{mL}$ of the di-organotin(IV) complexes and doxorubicin for 48 hours in an incubator. After that, the MTT solution was added and incubated for 4 hours in the dark. The absorbance measured at $570 \mathrm{~nm}$. The growth inhibition activity of organotin(IV) complexes expression by half-maximal inhibitory concentration ( $\mathrm{IC}_{50}$ ), which elucidates the molar concentration of the compounds that inhibit $50 \%$ of cell proliferation compared to untreated cells [18]. Statistical data and $\mathrm{IC}_{50}$ values are shown in Table 1, and Figure 2 shows the effect of complexes and their concentrations in the viability of A549 cells.

Table 1. Statistical data and $\mathrm{IC}_{50}$ values of complexes and control effect of the viability of A549 cells.

\begin{tabular}{l|l|l|l|l}
\multirow{2}{*}{$(\boldsymbol{\mu g} / \mathbf{m L})$} & \multicolumn{3}{|l|}{ Mean \pm SE of the viability of A549 cells } & LSD value \\
\cline { 2 - 5 } & doxorubicin & $\mathrm{Ph}_{2} \mathrm{SnL}_{2}$ & $\mathrm{Bu}_{2} \mathrm{SnL}_{2}$ & \\
\hline $\mathbf{0}$ & $100.00 \pm 0.00$ & $100.00 \pm 0.00$ & $100.00 \pm 0.00$ & $0.00 \mathrm{NS}$ \\
\hline $\mathbf{6 . 2 5}$ & $84.20 \pm 4.39$ & $90.65 \pm 3.92$ & $15.37 \pm 0.72$ & $9.543^{*}$ \\
\hline $\mathbf{1 2 . 5}$ & $54.29 \pm 2.41$ & $88.75 \pm 3.52$ & $12.99 \pm 0.54$ & $8.461^{*}$ \\
\hline $\mathbf{2 5}$ & $33.00 \pm 1.75$ & $80.82 \pm 3.28$ & $8.39 \pm 0.46$ & $11.594^{*}$ \\
\hline $\mathbf{5 0}$ & $4.69 \pm 0.14$ & $46.90 \pm 2.71$ & $7.92 \pm 0.37$ & $8.955^{*}$ \\
\hline $\mathbf{1 0 0}$ & $3.52 \pm 0.08$ & $45.48 \pm 1.42$ & $7.76 \pm 0.25$ & $7.842^{*}$ \\
\hline $\mathbf{L S D}$ value & $11.664 *$ & $9.578 *$ & $11.052 *$ & - \\
\hline $\mathbf{I C} \boldsymbol{5 0} \%$ & 14.91 & 67.88 & 0.03631 & - \\
\hline
\end{tabular}

$*=(\mathbf{P}<0.05)$ Similar litters mean the absence of significant differences

LSD $=$ Least Significant Difference

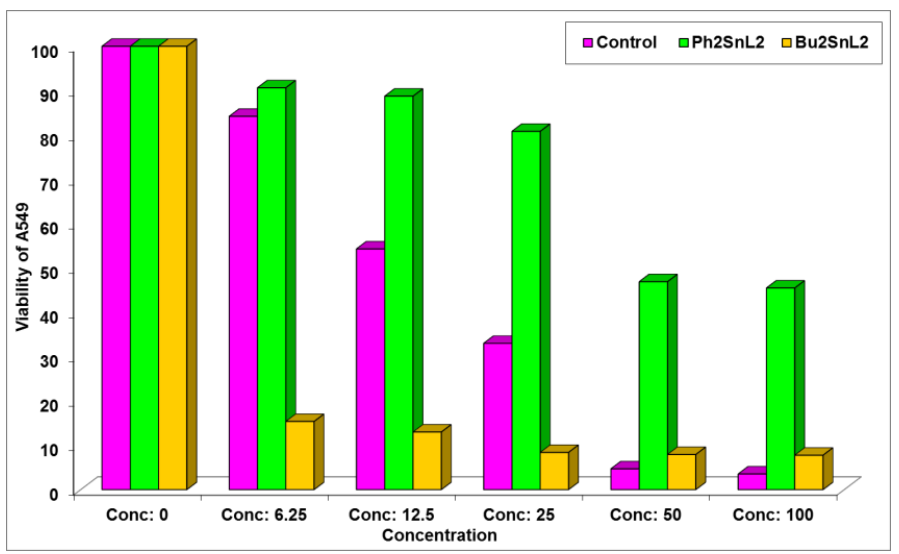

Figure 2. Effect of complexes and their concentrations in the viability of A549 cells.

The results show that the $\mathrm{Bu}_{2} \mathrm{SnL}_{2}$ has a higher activity to inhibit the growth of A549 cells compared to the $\mathrm{Ph}_{2} \mathrm{SnL}_{2}$, and doxorubicin. Although, at high concentrations (50 and 100) $\mu \mathrm{g} / \mathrm{mL}$ the doxorubicin more affective to inhibit the viability of A549 cells. The IC50 value of $\mathrm{Bu}_{2} \mathrm{SnL}_{2}$ in A549 cells higher than those of doxorubicin, $\mathrm{Ph}_{2} \mathrm{SnL}_{2}$ and also for investigated diand tri-organotin compounds $\left(\mathrm{R}_{2} \mathrm{SnL}_{2}\right.$ and $\mathrm{R}_{3} \mathrm{SnL}$, where $\mathrm{R}$ are $\mathrm{Me}, \mathrm{Bu}$ or $\mathrm{Ph}$, and $\mathrm{L}$ is $3-(1 \mathrm{H}-$ indol-3-yl)propanoate) in human ovarian carcinoma cells line (A2780) by Shaheen et al. [19]. The activity of organotin(IV) compounds to inhibit the growth cells effected by lipophilicity, van der Waals volume, and bulky specialties of an organic group that attaches to the tin atom 
as reported by Ullah et al. [20]. The lipophilicity of the n-butyl group is larger than the phenyl group. The presence of Sn-O bond and amino group in organotin(IV) complexes significantly improve antitumor activity against several types of cell lines. The nature of the substituent ligand (valsartan) is useful to transport the organotin moiety cross the cellular membrane and hydrolyzed $[21,22]$.

\subsection{Cell cycle phase distribution of A549 cells.}

Cell cycle phase distribution of the A549 cells was investigated by the flow cytometer to detect the DNA content after cells staining with annexin-V FITC and propidium iodide. Annexin V-Fluorescein isothiocyanate (Annexin V-FITC) binds to phosphatidylserine (PS) that found in the inner membrane of normal cells. Propidium iodide (PI) is a dye combines with annexin- $\mathrm{V}$ in order to estimate the apoptosis and necrotic cells. Normal cells are negative for both markers, apoptosis cells are positive for annexin- $\mathrm{V}$, and necrotic cells are positive for both markers. From the results, as shown in Figures 3 and 4, and tabulated in Table 2, early apoptotic cells Annexin V-FITC positive and PI negative. In contrast, late apoptotic and necrotic cells are V-FITC positive and PI-positive. DNA fragmentation occurs during the late stage, while in the early stage apoptosis, the mitochondrial membrane loses it is potential [23,24].

Table 2. Effect of $\mathrm{Bu}_{2} \mathrm{SnL}_{2}$ complex in apoptosis of A549 cells.

\begin{tabular}{l|l|l|l|l}
\multirow{2}{*}{ Group } & \multicolumn{3}{|c|}{ Apoptosis } & \multirow{2}{*}{ Necrosis } \\
\cline { 2 - 4 } & Viable Cell & Early & Late & \\
\hline A549 Cells+ Bu2SnL2 & $83.79 \pm 1.05$ & $4.36 \pm 0.23$ & $10.13 \pm 0.38$ & $1.72^{*}$ \\
\hline A549 Cells & $97.83 \pm 0.07$ & $0.75 \pm 0.04$ & $0.36 \pm 0.02$ & $1.06 *$ \\
\hline T-Test & $3.482 *$ & $1.597 *$ & $3.047 *$ & -- \\
\hline
\end{tabular}

$*=(\mathbf{P}<0.05)$ Similar litters mean the absence of significant differences
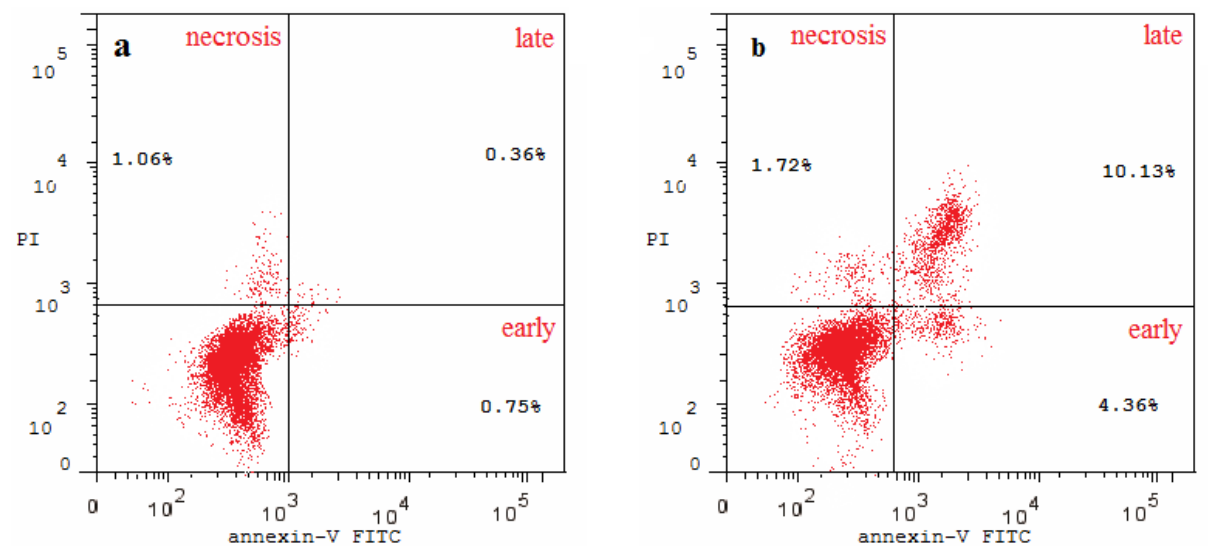

Figure 3. Viable cells, apoptosis, and necrosis of (a) A549 cells (untreated cells) and (b) $\mathrm{Bu}_{2} \mathrm{SnL}_{2}$ complex in A549 cells measured by flow cytometry (Annexin-V FITC/PI staining).

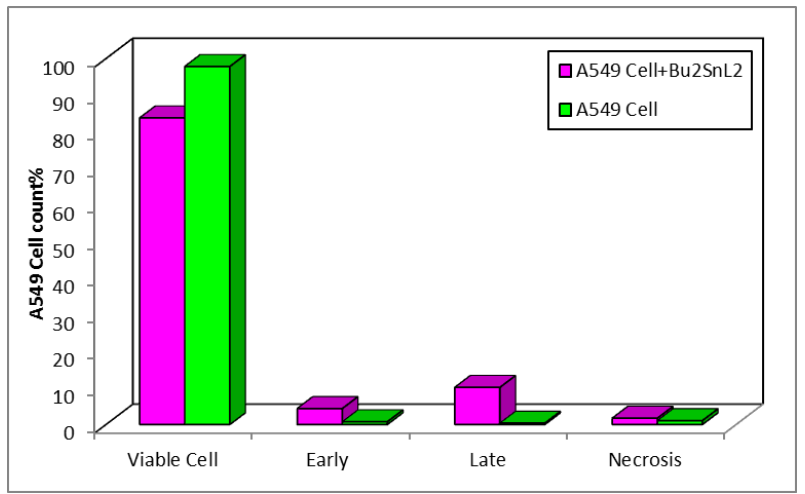

Figure 4. Effect of $\mathrm{Bu}_{2} \mathrm{SnL}_{2}$ complex in apoptosis results. 
The early and late apoptotic A549 cells identify by Annexin V-FITC conjugation with PI [25]. The presence of the $\mathrm{Bu}_{2} \mathrm{SnL}_{2}$ complex increases the percentage of early and late apoptotic cells, and decrease the percentage of the viable cells. $\mathrm{Bu}_{2} \mathrm{SnL} 2$ complex has proven its activity to damage $10 \%$ of the DNA and disrupt $4 \%$ of mitochondrial membrane potential. In a recent study, organoselenium-tin complexes with $\mathrm{R}=\mathrm{di}-\mathrm{n}-\mathrm{Bu}\left(\mathrm{n}-\mathrm{Bu}_{2} \mathrm{Sn}\left(\mathrm{O}_{2} \mathrm{CCH}_{2} \mathrm{SeC}_{6} \mathrm{H}_{4} \mathrm{~F}-\right.\right.$ p)2) damaged $0.43 \%$ of DNA, while disrupting $21 \%$ of mitochondrial membrane potential in human breast cancer cell lines (MDA-MB-231) which have higher cytotoxicity than organoselenium-tin complexes with $\mathrm{R}=$ tri-n-Bu or di- and tri-Me [26].

The development of anticancer drugs depends on the induction of cell cycle arrest and apoptosis. Restraining the cell cycle, in the case of tumor cells will inhibit the cell proliferation and lead to programmed cell death. Figure 5 shows the fluorescence microscopy histogram of A549 cells in the absence and presence of the $\mathrm{Bu}_{2} \mathrm{SnL}_{2}$ complex, which explains the cell cycle stages, including G0/G1, S, G2/M, and pre G1. The results revealed that the percentage of A549 cells in G2/M and G1 phases dramatically increased in the presence of the $\mathrm{Bu}_{2} \mathrm{SnL}_{2}$ complex, the accumulation of treated A549 cells with the $\mathrm{Bu}_{2} \mathrm{SnL}_{2}$ complex suggested that the cell cycle in the G2/M and pre G1 phases were blocked. The results improve that the organotin moieties after hydrolyzed might be interacted with protein kinases and DNA or binding to DNA through phosphate group, as reported by Kaluđerović et al. for triphenyltin(IV) chloride carboxylate complexes in human colon adenocarcinoma cells line (DLD-1) [27], While in S and G0/G1 phases, A549 cells significantly decrease, which denotes the cell growth inhibited in these phases [28]. Table 3 and Figure 6 show the A549 cells percentage content in each phase. The mitochondrial membrane potential (MMP) in the presence of $\mathrm{Bu}_{2} \mathrm{SnL}_{2}$, several substrates, may not fully be oxidized by the mitochondrial tri-carboxylic acid (TCA-cycle); these substrates observed as the accumulation of $\alpha$-keto acids, pyruvic acid, and $\alpha$ ketoglutarate. The $\mathrm{Bu}_{2} \mathrm{SnL}_{2}$ suggested inhibiting the $\alpha$-ketoglutarate and pyruvate dehydrogenase in mitochondria [29].

Table 3. DNA content $\%$ in the presence of the $\mathrm{Bu}_{2} \mathrm{SnL}_{2}$ complex in A549 cells.

\begin{tabular}{|c|c|c|c|c|}
\hline \multirow[t]{2}{*}{ Group } & \multicolumn{4}{|c|}{ DNA content \% } \\
\hline & G0/G1 & $S$ & G2/M & Pre G1 \\
\hline $\begin{array}{ll}\mathrm{A5499} & \text { Cell+ } \\
\mathrm{Bu}_{2} \mathrm{SnL}_{2} & \end{array}$ & $\begin{array}{l}35.66 \\
\pm 1.27\end{array}$ & $\begin{array}{l}24.18 \\
\pm \\
1.36\end{array}$ & $\begin{array}{l}40.16 \\
\pm \\
2.05\end{array}$ & $16.21 \pm 0.46$ \\
\hline A549 Cell & $\begin{array}{l}49.71 \\
\pm 2.08\end{array}$ & $\begin{array}{l}33.09 \\
\pm \\
2.54 \\
\end{array}$ & $\begin{array}{l}17.20 \\
\pm \\
0.87\end{array}$ & $2.17 \pm 0.07$ \\
\hline T-Test & $\begin{array}{l}6.522 \\
*\end{array}$ & $\begin{array}{l}5.742 \\
*\end{array}$ & $\begin{array}{l}6.835 \\
*\end{array}$ & $4.279 *$ \\
\hline
\end{tabular}

$*=(\mathbf{P}<0.05)$ Similar litters mean the absence of significant differences
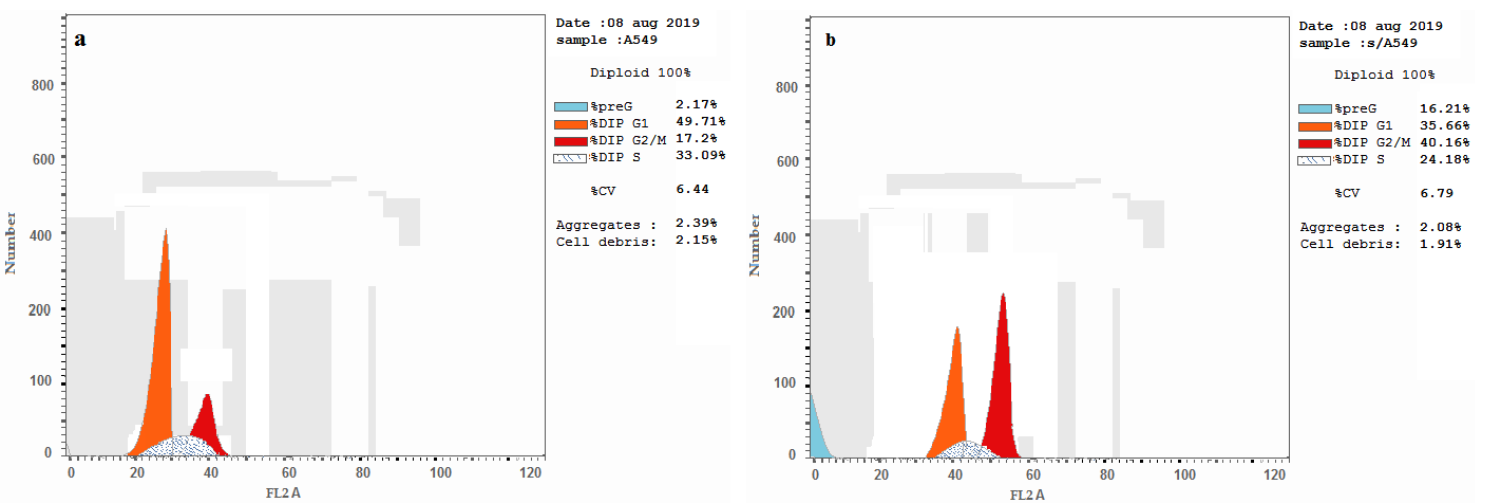

Figure 5. Fluorescence microscopy histogram of (a) A549 cells and (b) A549 cells in presence of $\mathrm{Bu}_{2} \mathrm{SnL}_{2}$ complex. 


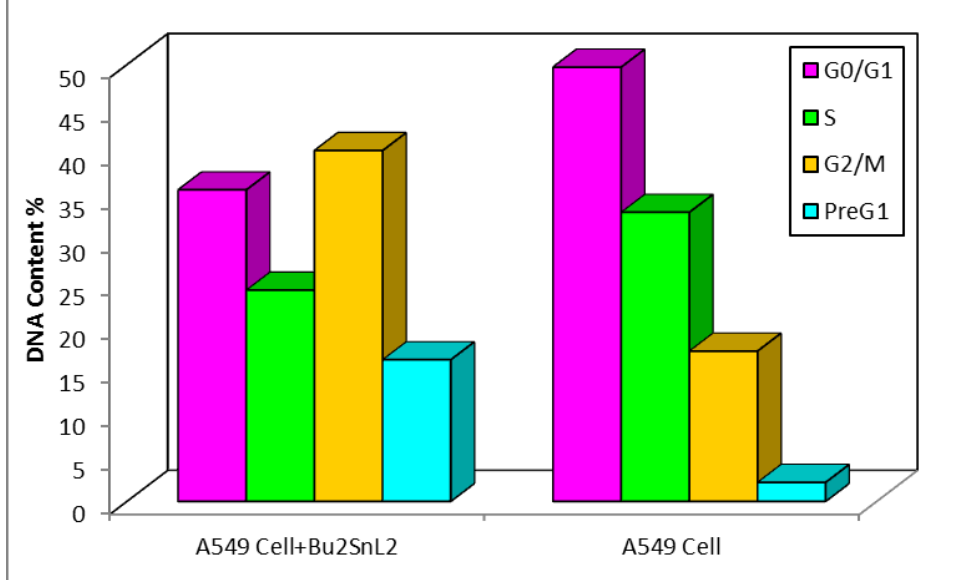

Figure 6. A549 cells content \% in the presence of the $\mathrm{Bu}_{2} \mathrm{SnL}_{2}$ complex in A549 cells.

\section{Conclusions}

The cytotoxic effect of the organotin(IV) complexes was investigated by using MTT colorimetric assay. Results showed that the $\mathrm{Bu}_{2} \mathrm{SnL}_{2}$ was more active in inhibiting the growth of A549 cells compared to the $\mathrm{Ph}_{2} \mathrm{SnL}_{2}$. Cell cycle phase distribution for the A549 cells was investigated by flow cytometer since $\mathrm{Bu}_{2} \mathrm{SnL}_{2}$ prove its activity to damage the DNA in $10 \%$ percentage and disruption of mitochondrial membrane potential in $4 \%$ percentage. The results revealed that the percentage of A549 cells in G2/M and pre G1 phases dramatically increased in the presence of the $\mathrm{Bu}_{2} \mathrm{SnL}_{2}$ complex. At the same time, the existence of these cells in $\mathrm{S}$ phase was significantly decreased and also decreased in the G0/G1 phase. These results improve that the $\mathrm{Bu}_{2} \mathrm{SnL}_{2}$ complex blocked the cell cycle in the $\mathrm{G} 2 / \mathrm{M}$ phase and inhibit the cell growth in $\mathrm{S}$ and $\mathrm{G} 0 / \mathrm{G} 1$ phases.

\section{Funding}

This research received no external funding.

\section{Acknowledgments}

The authors like to thanks Al-Nahrain University.

\section{Conflicts of Interest}

The authors declare no conflict of interest.

\section{References}

1. Levy, J.T. The Risen Publishing Group. 1st ed; Inc.: New Yourk, 2009; pp. 27-29.

2. Pereyre, M.; Quintard, J.; Rahm, A. General organotin chemistry. In: Tin in Organic Synthesis. 1st ed.; Pereyre, M.; Quintard, J.P.; Rahm, A. Eds:, Butterworth-Heinemann: UK., 1987; pp. 3-7, https://doi.org/10.1016/c2013-0-04077-7.

3. Ellahioui, Y.; Prashar, S.; Gómez-Ruiz, S. Anticancer Applications and Recent Investigations of Metallodrugs Based on Gallium, Tin and Titanium. Inorganics 2017, 5, 1-23, https://doi.org/10.3390/inorganics5010004.

4. Devi, J.; Yadav, J. Recent Advancements in Organotin(IV) Complexes as Potential Anticancer Agents, AntiCancer Agents in Medicinal Chemistry 2018, 18, 335-353, https://doi.org/10.2174/1871520617666171106125114.

5. Hunakova, L.; Horvathova, E.; Majerova, K.; Bobal, P.; Otevrel, J.; Brtko, J. Genotoxic Effects of Tributyltin and Triphenyltin Isothiocyanates, Cognate RXR Ligands: Comparison in Human Breast Carcinoma MCF 7 and MDA-MB-231 Cells. Int. J. Mol. Sci. 2019, 20, 1198; https://doi.org/10.3390/ijms20051198. 
6. Adeyemi, J.O.; Onwudiwe, D.C.; Ekennia, A.C.; Anokwuru, C.P.; Nundkumar, N.; Singh, M.; C.Hosten, E. Synthesis, characterization and biological activities of organotin(IV) diallyldithiocarbamate complexes. Inorganica Chimica Acta 2019, 485, 64-72. https://doi.org/10.1016/j.ica.2018.09.085.

7. Rehman, W.; Badshah, A.; Rahim, F.; Baloch, M.K.; Ullah, H.; Abid, O.; Nawaz, M.; Tauseef, I. Synthesis, spectral characterization, antibacterial and antitumor studies of some diorganotin(IV) complexes derived from 2-phenylmonomethylglutarate. Inorganica Chimica Acta 2014, 423, 177-182, https://doi.org/10.1016/j.ica.2014.08.006.

8. Ali, S.; Shahzadi, S.; Imtiaz-ud, D. Anticarcinogenicity and Toxicity of Organotin(IV) Complexes: A Review. Iran J Sci Technol Trans Sci 2018, 42, 505-524, https://doi.org/10.1007/s40995-016-0048-1.

9. Rom, W.N.; Tchou-Wong, K.M. Molecular and Genetic Aspects of Lung Cancer. In: Lung Cancer. Driscoll, B. ed.; Methods in Molecular Medicine ${ }^{\mathrm{TM}}$, Humana Press, Totowa, NJ, 2003; pp. 3-26, https://doi.org/10.1385/1-59259-324-0:03.

10. Ventura, E.; Giordano A. Cell Cycle. In Reference Module in Life Sciences, Elsevier, 2019, https://doi.org/10.1016/b978-0-12-809633-8.90189-4.

11. Corea, L.; Cardoni, O.; Fogari, R.; Innocenti, P.; Porcellati, C.; Provvidenza, M.; Meilenbrock, S.; Sullivan, J.; Bodin, F. Valsartan, a new angiotensin II antagonist for the treatment of essential hypertension: A comparative study of the efficacy and safety against amlodipine. Clin. Pharmacol. Ther 1996, 60, 341-346, https://doi.org/10.1016/s0009-9236(96)90061-2.

12. Abraham, I.; MacDonald, K.; Hermans, C.; Aerts, A.; Lee, C.; Brié, H.; Vancayzeele, S. Real-world effectiveness of valsartan on hypertension and total cardiovascular risk: review and implications of a translational research program. Vasc. Health Risk Manag 2011, 7, 209-235, https://doi.org/10.2147/vhrm.s9434.

13. Dadzie, I.; Avorgbedo, S.A.; Appiah-Opong, R.; Cudjoe, O. Cytotoxic and Antioxidant Effects of Antimalarial Herbal Mixtures. International Journal of Microbiology 2020, 1-5. https://doi.org/10.1155/2020/8645691.

14. Gorry, M.; Yoneyama, T.; Vujanovic, L.; Moss, M.L.; Garlin, M.A.; Miller, M.A; Herman, J.; Stabile, L.P.; Vujanovic, N.L. Development of flow cytometry assays for measuring cell-membrane enzyme activity on individual cells. Journal of Cancer 2020, 11, 702-715, https://doi.org/10.7150/jca.30813.

15. Mohammed, A.; El-Hiti, G.A.; Yousif, E.; Ahmed, A.A.; Ahmed, D.S.; Alotaibi, M.H. Protection of Poly(Vinyl Chloride) Films against Photodegradation using Various Valsartan Tin Complexes. Polymers 2020, 12, 1-18, https://doi.org/10.3390/polym12040969.

16. Nikbakht, M.; Pakbin, B.; Brujeni, G.N. Evaluation of a new lymphocyte proliferation assay based on cyclic voltammetry; an alternative method. Scientific Reports 2019, 9, 4503. https://doi.org/10.1038/s41598-01941171-8.

17. Kumari, R.; Mishra, R.C.; Yadav, J.P. Antioxidant and cytotoxic studies of Acacia nilotica twig extract and their green synthesized silver nanoparticles. Letters in Applied NanoBioScience 2020, 9, 975-980. https://doi.org/10.33263/LIANBS92.975980.

18. Bai, G.; Matsuba, T.; Kikuchi, H.; Chagan-Yasutan, H.; Motoda, H.; Ozuru, R.; Yamada, O.; Oshima, Y.; Hattori, T. Inhibition of inflammatory-molecule synthesis in THP-1 cells stimulated with phorbol 12myristate 13-acetate by brefelamide derivatives. Int Immunopharmacol. 2019, 75, 105831. https://doi.org/10.1016/j.intimp.2019.105831.

19. Shaheen, F.; Ali, S.; Shahzadi, S. Synthesis, Characterization, and Anticancer Activity of Organotin(IV) Complexes with Sodium 3-(1H-Indol-3-yl)propanoate. Russian Journal of General Chemistry 2017, 87, 2937-2943, https://doi.org/10.1134/s1070363217120350.

20. Ullah, H.; Previtali, V.; Mihigo, H.B.; Twamley, B.; Rauf, M.K.; Javed, F.; Waseem, A.; Baker, R.J.; Rozas, I. Structure-activity relationships of new Organotin(IV) anticancer agents and their cytotoxicity profile on HL-60, MCF-7 and HeLa human cancer cell lines. European Journal of Medicinal Chemistry 2019, 181, 110, https://doi.org/10.1016/j.ejmech.2019.07.047.

21. Nagy, L.; Pellerito, L.; Fiore, T.; Nagy, E.; Pellerito, C.; Szorcsik, A.; Scopelliti, M. Chapter 4 - Equilibrium, Structural and Biological Activity Studies on [Organotin(IV)]n+ Complexes. In: Advances in Organometallic Chemistry. Hill, A.F.; Fink, M.J. Eds. Academic Press: Volume 57, 2008; pp. 353-447, https://doi.org/10.1016/S0065-3055(08)00004-X.

22. Rao, D.P. A review on versatile applications of novel Schiff bases and their metal complexes. Letters in Applied NanoBioScience. 2019, 8, 675-681. https://doi.org/10.33263/LIANBS84.675681.

23. Abrahamsen, J.F.; Bakken, A.M.; Bruserud, Ø.; Gjertsen, B.T. Flow cytometric measurement of apoptosis and necrosis in cryopreserved PBPC concentrates from patients with malignant diseases. Bone Marrow Transplantation 2002, 29, 165-171, https://doi.org/10.1038/sj.bmt.1703346.

24. Brauchle, E.; Thude, S.; Brucker, S.Y.; Schenke-Layland, K. Cell death stages in single apoptotic and necrotic cells monitored by Raman microspectroscopy. Scientific Reports 2014, 4, 1-9, https://doi.org/10.1038/srep04698.

25. Nordin, M.L.; Abdul Kadir, A.; Zakaria, Z.A.; Othman, F.; Abdullah, R.; Abdullah, M.N.H. Cytotoxicity and Apoptosis Induction of Ardisia crispa and Its Solvent Partitions against Mus musculus Mammary 
Carcinoma Cell Line (4T1). Evidence-Based Complementary and Alternative Medicine 2017, 2017, 1-10, https://doi.org/10.1155/2017/9368079.

26. Qiu, Y.; Zhang, R.; Zhang, S.; Cheng, S.; Li, Q.; Ma, C. Novel organotin(iv) complexes derived from 4fluorophenyl-selenoacetic acid: synthesis, characterization and in vitro cytostatic activity evaluation. New Journal of Chemistry 2017, 41, 5639- 5650, https://doi.org/10.1039/c7nj00500h.

27. Kaluđerović, G.N.; Kommera, H.; Hey-Hawkins, E.; Paschke, R.; Gómez-Ruiz, S. Synthesis and biological applications of ionic triphenyltin(iv) chloride carboxylate complexes with exceptionally high cytotoxicity. Metallomics 2010, 2, https://doi.org/10.1039/c0mt00007h.

28. Guo, J.; Chen, Q.; Lam, C.W.; Zhang, W. Effects of karanjin on cell cycle arrest and apoptosis in human A549, HepG2 and HL-60 cancer cells. Guo et al. Biol Res 2015, 48, 1-7, https://doi.org/10.1186/s40659015-0031-x.

29. Gielen, M. Tin-Based Antitumour Drugs. 1st ed.; Springer-Verlag Berlin Heidelberg, 1990; pp. 173. 